\title{
LIFE-BASED CITIZENSHIP EDUCATION TEXTBOOK FOR VOCATIONAL HIGH SCHOOLS
}

\author{
M. Alifudin Ikhsan \\ Magister Program for Pancasila and Citizenship Education Universitas Negeri Malang \\ Jalan Semarang 5 Malang \\ email: alifudin.1707128@students.um.ac.id
}

\begin{abstract}
: this article discusses learning innovations for developing decent life-based textbooks in Vocational High Schools. The study produced a product in the form of a Pancasila and Citizenship Education textbook integrated with character values. This book was developed based on the characteristics of Vocational High School students, the character education content and applicable learning curriculum. The assessment of media experts, design and learning experts shows this learning book is valid. The results of trials on students indicate that this learning book can be used to improve the quality of learning, but a number of dimensions of special practicality need to be considered in the next testing phase.

Keywords: life based curriculum, Citizenship Education, vocational school Textbooks

Abstrak: penulisan artikel ini membahas tentang inovasi pembelajaran untuk mengembangkan buku ajar berbasis kehidupan yang layak di sekolah menengah kejuruan. Kajian menghasilkan produk berupa buku ajar Pendidikan Pancasila dan Kewarganegaraan yang terintegrasi dengan nilai-nilai karakter. Buku ini dikembangkan berdasarkan karakteristik siswa sekolah menengah kejuruan, muatan pendidikan karakter serta kurikulum pembelajaran yang berlaku. Penilaian ahli media, desain dan ahli pembelajaran menunjukkan buku pembelajaran ini valid. Hasil uji coba pada siswa menunjukkan bahwa buku pembelajaran ini dapat digunakan untuk meningkatkan kualitas pembelajaran, namun sejumlah dimensi kepraktisan khusus perlu diperhatikan dalam tahapan selanjutnya.
\end{abstract}

Kata Kunci: kurikulum berbasis kehidupan, Pendidikan Kewarganegaraan, buku ajar SMK

\section{INTRODUCTION}

Education is an essential part of lives. Education and teaching are needed to glorify humans (Nurwardani, 2016) and humanizing humans (Kusumawardani, 2013). In reality, education's purpose is to create an independent, responsible, characterized, knowledgeable, and creative human through a conscious and planned efforts in a learning process (Republik Indonesia, 2003). Therefore, education is meant as a transformation media of character instillation and development in daily life (Erlis, 2015). Civics education is a moral values-based learning (Sukri, 2013) and is also based on national character (Sobri,
2004). Civics as an education of character and values is not only teaching knowledge (cognitive) and skills (psychomotor), but also focusing on the development of the students' attitude (affective) and character (Nurwardani, 2016).

Besides, Civics is also being taught in the consideration of various and fluctuative national conditions and developments (Maunah, 2014). Civics as and education of moral and value is expected to be able to create nasionalistic and homeland-loving beings (Ikhsan, 2017b). The previous studies have found the fact that there is an imbalanced learning-teaching dichotomy between Civics and other subjects (Rochmadi, 2018). One of 
the causes is the non-optimized innovations in learning and teaching (Maunah, 2014). It is strengthened by the research done in SMK Negeri 1 Malang (State Vocational High School 1 Malang) relating to the problem. From the 72 respondents as the object of field observation, as much as $64,2 \%$ of students feel that the teaching of Civics needs some innovations, and as much as $86,5 \%$ of students admit that it is difficult for them to get an appropriate Civics textbook. This problem is causing the learning and teaching process of Civics to be "teacher oriented" (Nurhasanuddin, 2016). Where as teacher should only be an education facilitator for the students (Kemdikbud, 2013). The lack of Civics textbooks for Vocational High School students has become one of the considerations of the researcher to develop a suitable textbook for the characteristics of Vocational High Schools. Currently, the teaching materials published by the government is universal and centralistic, so they are not adjusted to the needs and ability of the students in each level of education. This is one of the troubles causing the achievement of goals to be unmaximized, ineffective, and inefficient (Rochmadi, 2018). The Civics textbook is developed un the concept of life-based learning. This concept is one of the ways used to integrate the students' cognitive ability with the real life (Peterson, 2011).

The advantage of the development of this life-based textbook is how students would be able to think critically (Budiarto, 2012), active in the effort of effective learning (Zain, 2014), able to learn in a real-life context (Mcewan \& Jasinski, 2006) and the students will also be actively included in the teaching and learning process (Mangesa, 2014). The life-based learning Civics textbook is an alternative of learning strategies that is focusing on real-life context. Based on the previous studies, this approach is suitable to deliver the subject materials in Vocational High Schools which emphasizes practices and students' skills (Kennedy, Jimenez, Mayer, Mellor, \& Smith, 2002). Life-based learning itself is a teaching concept of Civics to relate or reflect the subject to real life situations (Cogan, Grossman, \& Kong, 2002).

This textbook is also developed based on the five principles of the strengthening of character building programmed by the Ministry of Culture and Education. The five principles are the religious, nationalistic, independent, integrated, and mutual cooperation value (Dalyono, 2017). These character values are included in the textbook because the integration of character building in textbooks is still uncommon. Moreover, it is also supported by the observational data found by the researcher, in which $57 \%$ of students hold the opinion that the current Civics textbook is lacking in the department of character building. Thus, this textbook is expected to build the character value of nationalism and loving homeland for the Vocational High School students.

\section{METHOD}

This is a research and development done in State Vocational High School 1 Malang (SMK Negeri 1 Malang). For the development model, it uses the model of ADDIE (West, Thomas, Bodily, Wright, \& Borup, 2017) which consists of analysis, design, development, implementation, and evaluation (Branch, 2009). The first step was analysis, or the step to analyze the development of the textbook suited to the needs of the targets. The development analysis of the textbook was done by seeing the condition of the students which are the target of this research. The needs analysis is also portraying the phenomenon of the current Civics observations. The process resulted in a detailed and through explanation towards the specification of the needed development of Citizenship Education textbooks. 
The second step was the design done for the life-based learning Civics textbook. In this step, a formulation of validation and questionnaire sheets was also done, along with the observation sheet of the implementation of teaching syntax which were going to be used in this research and development. The third step was the development, started by the development of instruments and indicators of validation for the life-based Citizenship Education textbook. Afterwards, the data analysis was done using the testing instruments and the indicators of the textbook. If the product have not been rated as valid, a revision is done. The validity test would be conducted until the product is rated as valid for the implementation.

The fourth step is the implementation of the product in the field. The teaching is conducted by a model teacher using the textbook being developed. After the teaching of materials, the students tested using the instrument of cognitive test included inside the developed book. In this step, the questionnaire sheets for user response are also spread to both the teacher and students. It is done to get the data related to the practicality value of usage for the life-based learning Citizenship Education textbook. The fifth step is the evaluation for the textbook. In this step, the researcher divided the testing sytem into two, that are experts' validation (experts of media, design, materials, and Civics), and the test for users. The instrument used in the testing system was the sheets for experts' validation and the questionnaire for users' response using the scale of Likert 1-5.

The data of this research is both quantitative and qualitative. The quantitative data is the result of calculation from the average score of each question components. Meanwhile, the qualitative data is the critic and advice given by the experts and product users. The result of this assessment would be used as the base to conduct some revisions towards the Civics textbook so that it will be easier for Citizenship Education education to create a nationalism spirit in the heart of the students.

\section{RESULT AND DISCUSSION}

\section{Development of Life-Based Citizenship Education Textbooks}

In a sense of reality, textbooks are urgently needed by students to increase their ability in studying the teaching materials delivered by teachers. Textbooks are holding an essential role in the implementation of learning and teaching activities (Anggria, 2018). The use of textbooks is able to encourage the knowledge and skills of students towards subject materials. However, we need to emphasize that teachers are the facilitator of learning, not a learning subject. Lestari (2013) stated that textbooks are able to give a space for teachers to deliver materials in a more chronological and systematic way, suitable for the basic competences to be achieved.

Primarily, the development of textbooks is not only focusing on how to make an innovation in making the learning process more interesting, but also focusing on how to contain various learning materials that are thoroughly developed. According to Sudjana (2013), fundamentally, textbooks have learning materials to be given to the students for a learning reference based on the current curriculum. With these materials, students will be able to achieve the learning objectives (Camellia, 2016).

The steps to create a textbook, according to Prastowo (2013) includes (1) analysing curriculum; (2) analysing learning sources; and (3) choosing and determining teaching materials. All of the three steps need to be done correctly and systematically because the three of them have a cause and effect relation (Hernawan, Permasih, \& Dewi, 2008). The development of teaching materials is done in order to add the references of the 
students and creating an active, creative, innovative, and characterized learning and teaching activity (Purnamasari, 2017). The development of teaching materials is the effort for teaching services suitable with the current curriculum standards which should be fulfilled by teachers (UNHAS, 2015).

Life-based learning is one of the new ways in learning pattern, from the segmental pattern into the integrated and interconnected learning ecology among personal lives, works, families, and free time utilization (Simatupang, 2016). This new learning pattern shows that studying is not limited to get scores, degrees, and sertificates, but also to improve capabilities, so that ability and skill can be developed accordingly to the students own passions, which in the end may increase the welfare of the students. According to Staron (2006) life-based learning proposes that learning for work is not restricted to learning at work. Learning is a multi-dimensional experience (Rochmadi, 2018). Life-based learning is the process to gain knowledge and skills, understanding the meaning of life, skillful in solving problems, and living life in balance and harmony. Life-based learning is focusing on the concept that learning from life is indeed the real learning (Rochmadi, 2018).

Life-based learning is in line with the new era knowledge-based Industry which needs knowledge workers who are ready to accept the challenge of working and learning in the environment that is getting more contemporer with a pressure flowing more contradictively, full of changes and differences (Callan, 2001). Thus, it shows the existence of learning in both the teachers and the students. Life-based learning is an approach in learning and teaching activity that is marked with a few characteristics (Staden \& Purcell, 2016) as follows: (1) the learning process needs to form the independence, the creativity, and the adaptability of students so that they are able to have an intact personality with a high integrity and a continuously developing talent. The learning and teaching process needs to be done in a comfortable, calm, fun, and character-value-based situations (Hasan, 2012); (2) each learning and teaching process needs to give a space for students to develop their own ability (Mangesa, 2014) and skill suitable to the current values and norms in the society (Knoors \& Marschark, 2014); (3) the learning and teaching process needs to integrate or combine daily life's components, so that the learning and teaching process can be done anywhere and in any conditions; (4) the atmosphere of the learning and teaching process needs to pierce the limits of life, not only physically, but also psychologically and socially (Claes, 2016); moreover, it should also admit and embrace the context of life broadly as the learning space for students (Rochmadi, 2018).

The research is directed towards the creation of nationalism spirit and character for Vocational high school students. As we know, vocational high schools are schools that are focusing on the development of the students for certain types of occupations (Ibrahim, Alias, \& Nordin, 2016). Vocational high schools prioritize the preparations of their students to enter the labor world (Kusumawardani, 2013) and develop a professional attitude (Schulz, 2016). In accordance to their form, vocational high schools provide some educational programs suitable with the types of job vacancies. According to The Law of National Education System Act. 20, 2003, vocational high schools are one of the forms of formal education providing vocational educationon the level of high school as the continuations of Junior High School, Islamic Junior High School, and other forms in the same level (Republik Indonesia, 2003). Vocational high schools can be named like that (Sekolah Menengah Kejuruan/SMK), or Islamic Vocational high school (madrasah aliyah kejuruan/ 
MAK), or in any other forms with the same level. The curriculum of vocational high schools are made so that the students would be ready to get a job, or for labor world. The contents of vocational high schools' curriculum are arranged in such a way to be suitable for the needs in laboring world (Budiarto, 2012).

The result of this research is a textbook which prioritize the instillation of nationalism spirit and values of loving the homeland for students. The character values included are based on the characteristics of vocational high school students. Picture 1 and 2 are some of the pages from the life-based textbook.

The character values in this book are inseparable from the materials and research of the book. The research conducted by (Schulz, 2016) shows that character values that are sticking to a book are able to give a fundamental understanding on each learning and teaching process. Character building is done by applying the character values in the content of the textbook. The character building values emphasized in this book is the religious, nasionalistic, independence, integrity, and cooperation values.

The character building values inside the textbook have been adjusted to suit the national program of mental revolution issued by the government. The strengthening of character education is an education movement at schools to strengthen the characters of the students through the harmonization of ethics, aesthetics, literacy and kinesthetic with the support of public integration and the cooperation among schools, families, and the society (Dalyono, 2017). The Regulation of the President of Indonesian Republic Number 87, year 2017, stated that the strengthening of character education is implemented by applying the values of Pancasila in character education, especially

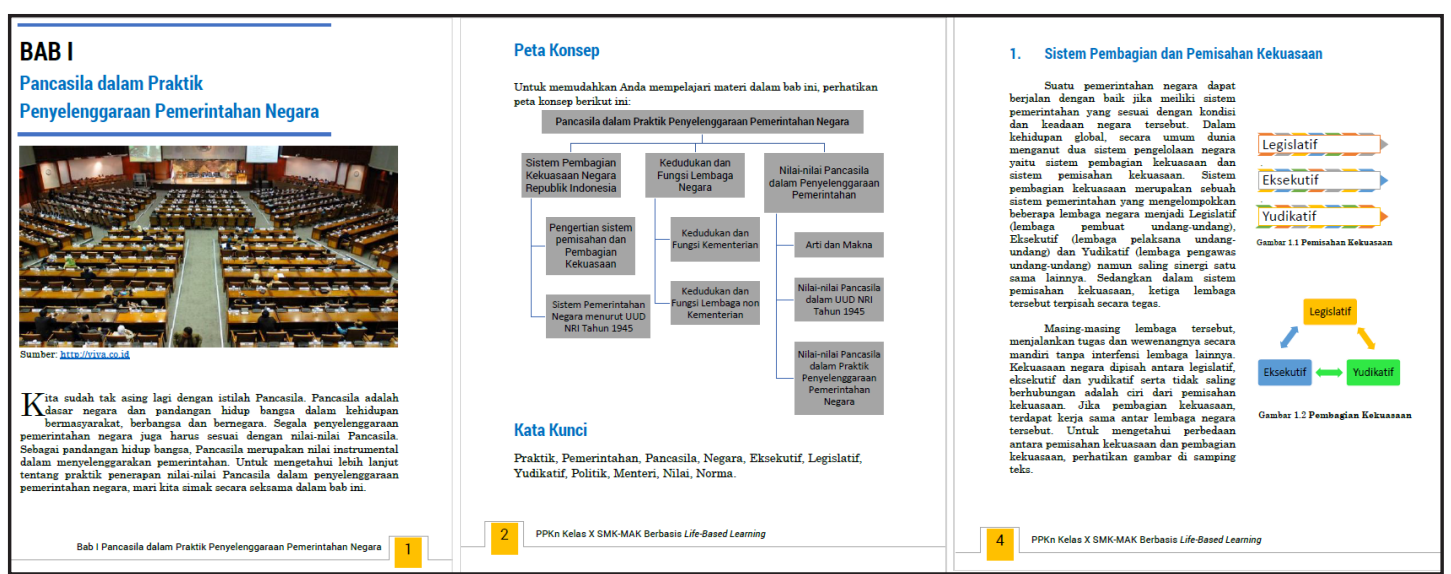

Picture 1. The content features of the textbook

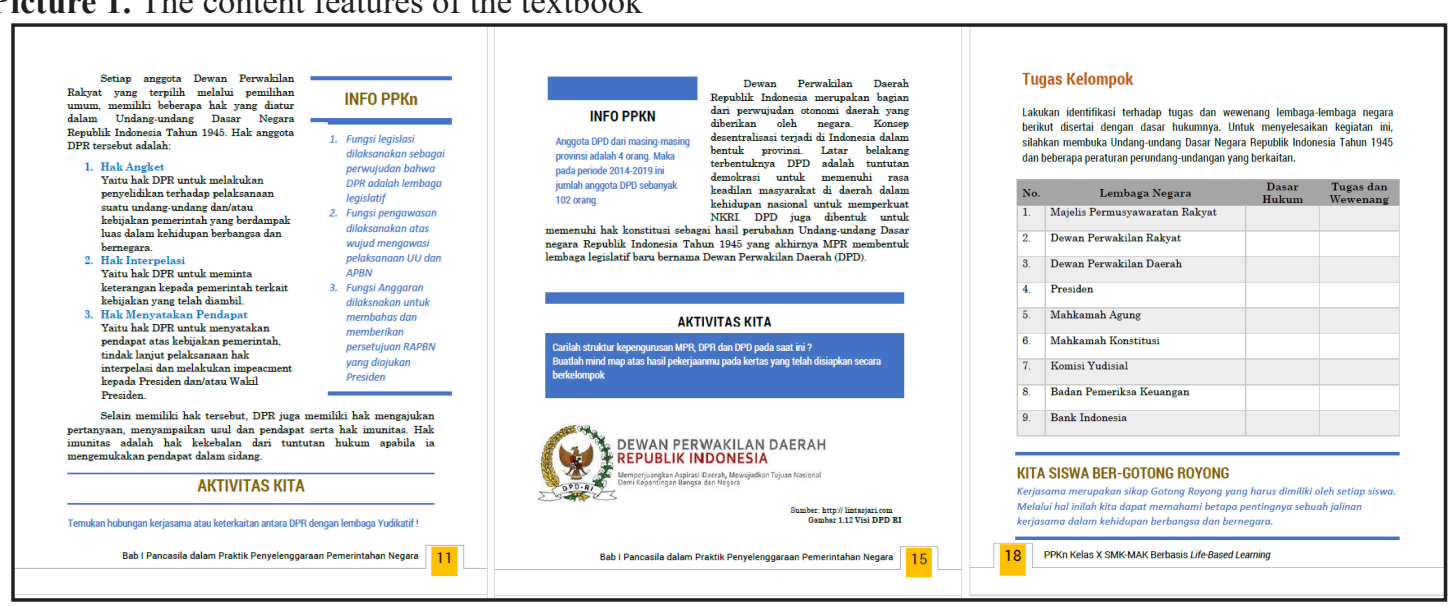

Picture 2. The feature of activity and group task 
Table 1. The Data Analysis of Needs and Contents

\begin{tabular}{lccc}
\hline Characteristics of textbooks & Teachers and Students & Education Experts & Qualification \\
\hline The need of textbooks & 5.0 & 5.0 & Highly needed \\
Character building values & 4.8 & 5.0 & Highly needed \\
Life education values & 4.8 & 5.0 & Highly needed \\
State affairs' information & 4.9 & 4.9 & Highly needed \\
\hline
\end{tabular}

on religious, honesty, tolerance, discipline, hard-working, creative, independence, democratic, curiosity, nationality, achievement appreciation, communicative, peace-loving, love reading, caring with environments, social care, and responsibility values (Sulistyadi, 2014).

This textbook is used by vocational high school students who have a different characteristic with other levels of education. In the learning and teaching process in vocational high schools, the priority is in soft skill menagement and students' personality. Civics, as a normative subject, has a strategic role in developing students' skill and attitude to strengthen the spirit of nationalism and humans' equality (Ikhsan, 2017a).

The strengthening of nationalism spirit and character can also be seen in this textbook. Here are the results of the preliminary research related to how important the Civics textbook with the integration of character building is. The indicators used are calculated using the likert scale of 1-5.

The result of the research shows that there is a high interest to develop life-based Civics textbook. The book is developed with the emphasize on character building values to increase the nationalism spirit of Vocational High School students.

\section{CONCLUSION}

This research is trying to develop that charcter through the life-based Civics textbook. It is done in order to give a life experience capable of bringing the students into a citizen who is nationalistic, religious, independent, and has a high integrity in socializing and nationalizing. This research needs to be developed further by implementing it in the learning and teaching activities of Vocational High Schools. This research may also be developed by making life-based Civics teaching strategies and models with a greater and more comprehensive scope.

\section{REFERENCES}

Budiarto, A. (2012). Penerapan Strategi Pembelajaran CTL ( Contextual Teaching \& Learning) Untuk Meningkatkan Keaktifan Dan Hasil Belajar Siswa Kelas Xi Jurusan Teknik Kendaraan Ringan Pada Mata Pelajaran Sistem Pengapian di SMK Muhammadiyah 1 Bantul (Skripsi, Issue November). Universitas Negeri Yogyakarta.

Camellia. (2016). Bahan Ajar Pendidikan Pancasila dan Kewarganegaraan (PPKn) berbasis Nilai-Nilai Karakter dalam Membentuk Sikap/Watak Kewarganegaraan Siswa (Civic Dispositions). Jurnal Bhinneka Tunggal Ika, 3(1), 13-21.

Claes, E. (2016). Civic Meaningfulness. Foundations of Science, 21(2), 347372. https://doi.org/10.1007/s10699014-9396-5

Cogan, J. J., Grossman, D. L., \& Kong, H. (2002). Citizenship Education and the preparation of future teachers. Asia Pasific Education Review, 3(2), 168-183. https://doi.org/10.1016/j. jpba.2007.03.013

Dalyono, B. (2017). Implementasi penguatan pendidikan karakter di sekolah. Universitas Terbuka Semarang, 03, 33-42.

Erlis, R. (2015). Implementasi Pendidikan 
Karakter pada Kelas Inklusi di SD Negeri Widoro Kecamatan Pengasih Kabupaten Kulon Progo (Yuniarifi (ed.)). Universitas Negeri Yogyakarta.

Hasan, A. B. P. (2012). Policies and Practices for Promoting Multicultural Awareness of Indigenous Early Childhood Education in Indonesia. International Journal of Child Care and Educational Policy, 6(1), 63-94.

Hernawan, A. H., Permasih, \& Dewi, L. (2008). Panduan Pengembangan Bahan Ajar. Depdiknas Jakarta, 1-13. Ibrahim, Z., Alias, N., \& Nordin, A. B. (2016). Needs Analysis for Graphic Design Learning Module Based on Technology \& Learning Styles of Deaf Students. Cogent Education, 3, 2-14. https://doi.org/10.1080/23 31186X.2016.1178364

Ikhsan, M. A. (2017a). Fikih Ham Dan Hak Kebebasan Beribadah Minoritas Dzimmi Di Indonesia. Jurnal Ilmiah Pendidikan Pancasila Dan Kewarganegaraan, 2(1), 34-40. https:// doi.org/10.17977/um019v2i12017p034

Ikhsan, M. A. (2017b). Nilai - Nilai Cinta Tanah Air Dalam Perspektif AlQur' an. Jurnal Ilmiah Pendidikan Pancasila Dan Kewarganegaraan, 2(2), 108-114. https://doi.org/http://dx.doi. org/10.17977/um019v2i22017p108

Kebudayaan, M. P. dan. (2013). Peraturan Menteri Pendidikan dan Kebudayaan Republik Indonesia Nomor 70 Tahun 2013 Tentang Kerangka Dasar dan Struktur Kurikulum Sekolah Menengah Kejuruan/Madrasah Aliyah Kejuruan. In Peraturan Menteri Pendidikan dan Kebudayaan Republikn Indonesia Nomor 70 Tahun 2013 (Issue Standar Penilaian Pendidikan). https://doi. org/10.1017/CBO9781107415324.004

Kennedy, K. J., Jimenez, S., Mayer, D., Mellor, S., \& Smith, J. (2002). Teachers' conversations about civic education: Policy and practice in Australian schools. Asia Pacific Education Review, 3(1), 69-82. https://doi. org/10.1007/BF03024922

Knoors, H., \& Marschark, M. (2014). Teaching Deaf Learners: Psychological and Developmental Foundations. Oxford University Press.

Kusumawardani, M. (2013). Implementasi Nilai Nilai Pendidikan Karakter di Sekolah Menengah Kejuruan Negeri 4 Yogyakarta. Universitas Negeri Yogyakarta.

LPP UNHAS. (2015). Bahan Ajar, Buku Ajar, Modul, dan Panduan Praktik. Lembaga Pengembangan Pendidikan Dan Pembelajaran Universitas Hasanuddin Makassar.

Mangesa, R. T. (2014). Implementasi Pendekatan Kontekstual Dalam Pembelajaran Praktik Instalasi Listrik. Jurnal Kependidikan, Vol.46, No.1: Mei 2016, 110-120.

Maunah, B. (2014). The implementation of character education in the formation of students' holistic personality. IAIN Tulungagung, 2(1), 90-101. https:// doi.org/http://dx.doi.org/10.21831/ jpk.v0i1.8615

Mcewan, M., \& Jasinski, M. (2006). Life Based Learning In attendance (Issue May).

Nurwardani, P., Saksama, H. Y., \& Dkk. (2016). Pendidikan Pancasila. In Direktorat Jenderal Pembelajaran dan Kemahasiswaan Kementerian Riset Teknologi dan Pendidikan Tinggi.

Peterson, A. (2011). Civic republicanism and civic education: The education of citizens. In Civic Republicanism and Civic Education: The Education of Citizens. https://doi. org/10.1057/9780230306752

Purnamasari, N. L. (2017). Pengembangan bahan ajar mata pelajaran pendidikan kewarganegaraan sd kelas 5 dengan model r2d2 di sdn 1 mojoarum tulungagung. Jurnal Ilmiah Penelitian 
Dan Pembelajaran Informatika, 02(11), 99-106.

Republik Indonesia. (2003). Undang-Undang Nomor 20 Tahun 2003 Tentang Sistem Pendidikan Nasional: Vol. Tambahan L. Kementerian Hukum dan Hak Asasi Manusia.

Rochmadi, N. W. (2018). Rekonstruksi Kurikulum Pendidikan Pancasila dan Kewarganegaraan (PPKn) Berbasis Kehidupan (Life Based Learning). Makalah Seminar Nasional Pembelajaran PPKn.

Schulz, W. (2016). Civic and Citizenship Framework. International Association for the Evaluation of Educational Achievement (IEA), 12(20), 11-38. https://doi.org/D OI 10.1007/978-3319-39357-5 2

Simatupang, P. (2016). A Critical Review on Paradigm and Framework of National Food Security Policy. Forum Penelitian Agro Ekonomi, 25(7), 1-19.

Sobri, A. Y. (2004). Penyemaialn Nilai Karakter Melalui Program Penguatan Pendidikan Karakter di Sekolah. 63-72.

Staden, A. van, \& Purcell, N. (2016). Multi-Sensory Learning Strategies to Support Spelling Development: a Case Study of Second-Language
Learners with Auditory Processing Difficulties. International Journal on Language, Literature and Culture in Education, 3(1), 40-61. https://doi. org/10.1515/1lce-2016-0003

Sukri, S. (2013). Implementasi pendidikan karakterdi Sekolah Menengah Pertama Islam Terpadu (Smpit) Darul Azhar Aceh Tenggara.

Sulistyadi, H. K. (2014). Implementasi Kebijakan Penyelenggaraan Layanan Pendidikan Inklusif di Kabupaten Sidoarjo. Kebijakan Dan Manajemen Publik, 2, 1-10.

West, R. E., Thomas, R. A., Bodily, R., Wright, C., \& Borup, J. (2017). An analysis of instructional design and technology departments. Educational Technology Research and Development, 65(4), 869-888. https://doi.org/10.1007/ s11423-016-9490-1

Zain, R. (2014). Implementasi Strategi Pembelajaran Contextual Teaching and Learning (CTL) dan Concept Mapping berbasis Multiple Intelegence Terhadap Prestasi Belajar Akuntansi Mahasiswa Program Studi Pendidikan Ekonomi STKIP Hamzanwadi Selong Lombok Timur. Jurnal Pendidikan Insan Mandiri, Volume 3 N(3), 73-87. 